\title{
Animal food during the Late Prehispanic Period at Sierras of Córdoba, Argentina. A zooarchaeological view from Boyo Paso 2
}

\author{
Matías E. MEDINA \\ CONICET - División Arqueología, \\ Facultad de Ciencias Naturales y Museo, Universidad Nacional de La Plata, \\ Av. 122 y 60, La Plata 1900 (Argentina) \\ paleomedina@gmail.com (corresponding author)
}

Mailín CAMPOS Facultad de Filosofía y Letras, Universidad de Buenos Aires, Púan 480, Buenos Aires 1420 (Argentina)

Nancy ÁVILA

Facultad de Filosofía y Letras, Universidad de Buenos Aires, Púan 480, Buenos Aires 1420 (Argentina)

Esteban SOIBELZON

CONICET, División Paleontología de Vertebrados, Facultad de Ciencias Naturales y Museo, Universidad Nacional de La Plata, Paseo del Bosque s/n (1900), La Plata 1900 (Argentina)

Fernando J. FERNÁNDEZ

CONICET, Cátedra de Anatomía Comparada, Facultad de Ciencias Naturales y Museo, Universidad Nacional de La Plata, Calle 64 s/n (1900), La Plata (Argentina) and GEA, Facultad de Ingeniería, UBA. Av. Paseo Colón 850, Buenos Aires 1063 (Argentina)

KEY WORDS Sierras of Córdoba Late Prehispanic Period, zooarchaeology, foraging, subsistence, mixed economy.
Medina M. E., Campos M., Ávila N., Soibelzon E. \& Fernández F. J. 2019. - Animal food during the Late Prehispanic Period at Sierras of Córdoba, Argentina. A zooarchaeological view from Boyo Paso 2. Anthropozoologica 54 (10): $83-95$. https://doi.org/10.5252/anthropozoologica2019v54a10. http://anthropozoologica.com/54/10

\section{ABSTRACT}

How prehispanic foragers adjusted their foraging activities to plant cultivation is a question that drives much of the modern archaeological research. As a result, the spread of food-producing economies during the Late Prehispanic Period (c. 1500-360 BP) from Sierras of Córdoba, Argentina, has been recently defined as a dynamic sociocultural process, where a mixed foraging and cultivation economy was accompanied by a flexible land-use strategy. However, the economic organization has only been superficially assessed. Thus, the aim of this article is to present the study of faunal remains recovered during the excavation of the open-air site Boyo Paso 2 in order to provide primary data on the properties of the animal food remains left by late prehispanic people and the characteristics of site occupation. 
Faunal remains suggest a complex sequence of reoccupations where bones were deposited, accidentally reburned and fragmented by trampling. The diversity of exploited prey also sheds light on the fact that a broad hunting spectrum continued playing a key role in the daily subsistence. Nevertheless, cultigens were a fluctuating component in a diverse foraging economy in which wild resources as guanaco (Lama guanicoe Müller, 1776), small-vertebrates and Rheidae eggs continued to be extensively used. The study of Boyo Paso 2 faunal assemblage is relevant because it helps to improve the current understanding of the economic importance of foraging wild resources and would constitute a model to interpret other archaeological cases during the Neolithic or Formative transition, where the boundaries between farming and foraging were fluid, but remained relatively invisible according to the existing terminology.

\section{RÉSUMÉ}

Alimentation animale durant la Période préhispanique récente des chaînes de montagnes de Córdoba (Argentine): perspective archéozoologique de Boyo Paso 2.

La façon dont les chasseurs-cueilleurs préhispaniques ont adopté l'agriculture dans leur économie de subsistance est une question qui mobilise une grande partie de la recherche archéologique moderne. L'expansion des économies de production durant la Période préhispanique récente (c.1500-360 BP) des chaînes de montagnes de Córdoba (Argentine) a été récemment définie comme un processus socio-culturel dynamique, dans lequel une économie mixte de chasse-cueillette et d'agriculture a été couplée à une stratégie flexible d'exploitation du paysage. Cependant, l'organisation économique n'a été que partiellement évaluée. L'objectif de cet article est de présenter l'étude des restes osseux fauniques collectés durant la fouille du site de plein-air Boyo Paso 2, de façon à illustrer les spécificités des restes de consommation animale laissés par les populations préhispaniques récentes, ainsi que les caractéristiques de l'occupation du site. Les restes osseux suggèrent une séquence complexe de réoccupations durant lesquelles les ossements ont été déposés, brûlés accidentellement et fragmentés par piétinement. La diversité des proies exploitées révèle que le spectre de chasse élargi continue à jouer un rôle clef dans la subsistance quotidienne, alors que les cultigènes sont des composants fluctuants au sein d'une économie de chasse-cueillette diversifiée dans laquelle les ressources sylvestres comme le guanaco (Lama guanicoe (Müller, 1776)), les petits vertébrés et les œufs de Rheidae continuent à être extensivement consommés. L'analyse de l'assemblage faunique de Boyo Paso 2 est édifiant car il contribue à inverser les connaissances actuelles de l'importance économique de l'obtention des ressources sylvestres et devrait constituer un modèle pour interpréter d'autres cas archéologiques durant la transition néolithique ou formative, au cours de laquelle les limites entre l'agriculture et la chassecueillette ont été fluides, mais sont restées relativement invisibles selon la terminologie existante.

\section{INTRODUCTION}

The spread of domesticated plants and how prehispanic foragers initially adjusted their foraging activities to the labor demand of plant cultivation is one of the most interesting questions in archaeology (Price \& Gebauer 2003; Kennett \& Winterhalder 2006; Freeman 2012). During decades researchers have interpreted that the onset of farming and its dispersion across the world was associated with dramatic changes in human societies. It was assumed that plant cultivation quickly derived in a new mode of socioeconomic organization with a high reliance on domesticated plants and a sedentary way of life in year-round villages (Price \& Gebauer 2003; Bandy \& Fox 2010), where the role of foraging wild resources was understated or regarded as a complementary strategy at most. Fortunately, recent studies discredited this normative point of view, indicating that the way in which foragers add crops in their economy can be affected by many socio-ecological variables (i.e., foraging opportunities, farming constrains or human demography), resulting in a mosaic of foraging and farming pattern at different scales (see Layton et al. 1991; Barlow 2002; Denham et al. 2007; Amkreutz et al. 2008; Muscio 2009; Asouti \& Fairbairn 2010; Dillehay et al. 2011; Freeman 2012; Silva \& Frank 2013; Popov et al. 2014, among others). For example, Silva \& Frank (2013) deconstructed the Neolithic myth concluding that: "[...] Neolithic Western Europeans should then be regarded as horticuralists at most, with only a small percentage of their subsistence being catered for by products of farming and pastoralism, and not as full-fledged farmers [...]" (Silva \& Frank 2013: 231). Thus, a reply to the question of how prehispanic people fit conveniently both strategies is not straightforward and needs to be solved on the regionally-specific case-by-case basis (Barlow 2002; Amkreutz et al. 2008; Popov et al. 2014).

In Sierras of Córdoba, a low-altitude mountain range (500-2800 meters above sea level [m.a.s.l.]) located in central Argentina, the spread of food-producing economies during the Late Prehispanic Period (c. 1500-360 BP) has been recently defined as a dynamic sociocultural process (Pastor $e t$ al. 2012; Medina et al. 2016). The evidence suggests that late 
prehispanic people shifted settlement location and group size to take advantage of both domesticated and wild resource as became available (Medina et al. 2016). It is argued that during the growing season (September-April) few extended families settled in semi-permanent villages or hamlets to plant crops in small plots. When harvest and storage activities finished, coresidential groups dispersed across the landscape to forage and maintain the sociopolitical fluidity upon which they depended. The decline of foraging opportunities at early growing season was followed again by seasonally co-residence and small-scale farming. In consequence, the repeated reoccupation of late prehispanic villages created the illusion of large and extensive deposits that resemble the multi-household nucleated settlement of fully-sedentary agriculturalist, but represented semi-isolated habitational structures or hamlets discontinuously recouped over several centuries by a small-to-medium sized group of people that practiced a flexible land-use and a mixed subsistence strategy (Medina et al. 2016).

However, the economic organization during the Late Prehispanic Period has only been superficially assessed, even when zooarchaeological and archaeobotanical studies were carried out in recent years (see Pastor \& López 2010; Medina et al. 2011; Medina \& Pastor 2012; Medina et al. 2014; López 2015; López \& Recalde 2016; Rivero \& Medina 2016; Recalde \& López 2017; Medina et al. 2018). For example, the evidence of maize (Zea mays Linnaeus, 1753) or other crops plant cultivation is tenuous and the few recovered remains present problems to assess the importance of plant food in the prehispanic subsistence. In contrast, faunal remains are a conspicuous part of the late prehispanic record. Nevertheless, only recent published works include some form of preliminary analysis of faunal report suggesting that hunting might have been an important activity and probably impacted on the availability of the guanaco (Lama guanicoe (Müller, 1776)), the high ranked prey (Rivero \& Medina 2016). However, it stays uncertain how hunting was integrated into other aspects of economic organization and the evidence regarding late prehispanic subsistence remains largely conjectural.

The aim of this article is to present the study of faunal remains recovered during the recently excavated late prehispanic site Boyo Paso 2 (Valley of Salsacate, Córdoba Province). It is argued that a zooarchaeological approach to faunal remains can provide primary data on the properties and characteristics of the animal food remains left by late prehispanic people, the complex dynamic of site occupation and how hunting impacted on ancient environment. The article follows the hypotheses that the adoption of plant cultivation $c .1500 \mathrm{BP}$ did not produce any dramatic change in subsistence practices and that the late prehispanic people were characterized by a broad spectrum foraging base complemented by small-scale farming. Thus, the detailed information regarding formation process, as well as food procurement, preparation, consumption and discard practices is used to estimate the degree of reliance on specific faunal resource during the Late Prehispanic Period. The results obtained here are expected to help improve the current understanding of the importance of foraging wild resources in subsistence economies organized as seasonal or occasional food producers, improving the identification of these not well-documented archaeological groups from which few suitable frames of reference for their recognition in the record exist. Collected data should also serve as a useful model for interpreting many archaeological cases around the world during the early Neolithic or Formative transition, where potential movement out of farming to foraging - and vice versa - might be neglected by the use of unidirectional conceptions of cultural change.

\section{THE SITE AND ITS CHRONOLOGY}

Boyo Paso 2 is an open-air site located at 1160 m.a.s.l. in eastern Salsacate valley (Fig. 1). It is surrounded by slope circumscribed organich-rich soils for farming and a xerophytic forest dominated by small trees with edible fruits such as Prosopis spp. Linnaeus, 1762, Geoffroea decorticans (Hook. \& Arn.) Burkart, 1949, and Condalia microphylla Cavanilles \& Palop, 1799. The horizontal excavation revealed a slightly compacted archaeological floor with post-molds, a semi-subterranean structure and abundant refuse in plan, including a high diversity of projectile points, residues of such time-consuming activities as pottery making and the faunal remains analyzed here. The presence of habitational structures like pit-houses was inferred by the detection of 23 post-molds (Fig. 2). However, they overlap and do not form a pattern that can be traced to identify the shape or size of the structures, reinforcing the hypothesis that they were not durable habitational residences for long-time occupation. Artifacts left as abandonment refuse were found on the living floor, including bone tools, grinding tools and pottery vessels (Medina et al. 2016; Medina et al. 2018). Moreover, the identification of domesticated plant remains (Zea mays, Phaseolus vulgaris (Burkart) Baudet, 1977) and wild fruits (Sarcomphalus mistol (Griseb.) Hauenschild, 1874) suggests that site occupation was restricted to spring-summer at least when planting, harvesting and/or gathering of wild food were available around the site (Medina et al. 2016). The living floor was also rich in scattered ash and ash by-products, charcoals and some reddened earth rather than well-defined hearths, indicating that multiple burning events affected the deposit at coarse-grain. Carbonized seeds and charcoal samples collected from the archaeological floor were dated at $750 \pm 70 \mathrm{BP}$ (wood charcoal, LP-2932: 1205-1400 AD), 866 \pm 39 BP (Phaseolus vulgaris, AA110929: 1156-1277 AD), 878 \pm 18 BP (Zea mays, AA110928: 1162-1265 AD), 1060 50 BP (wood charcoal, LP-3122: 897-1155 AD) and 1500 $\pm 80 \mathrm{BP}$ (wood charcoal, LP-3107: 411-765 AD), confirming that it was formed over a long period, even when the artifacts look likely to conserve their original position (Medina et al. 2016). Thus, Boyo Paso 2 was interpreted as a seasonally reoccupied encampment where small groups of people with a mixed foraging and cultivation economy coalesced to do a wide range of activities. So, the faunal assemblage offers a viable match and an excellent opportunity to assess the human diet breadth through the Late Prehispanic Period, where tactics, actions and decisions were repeated at an evolutionary scale resolution. 


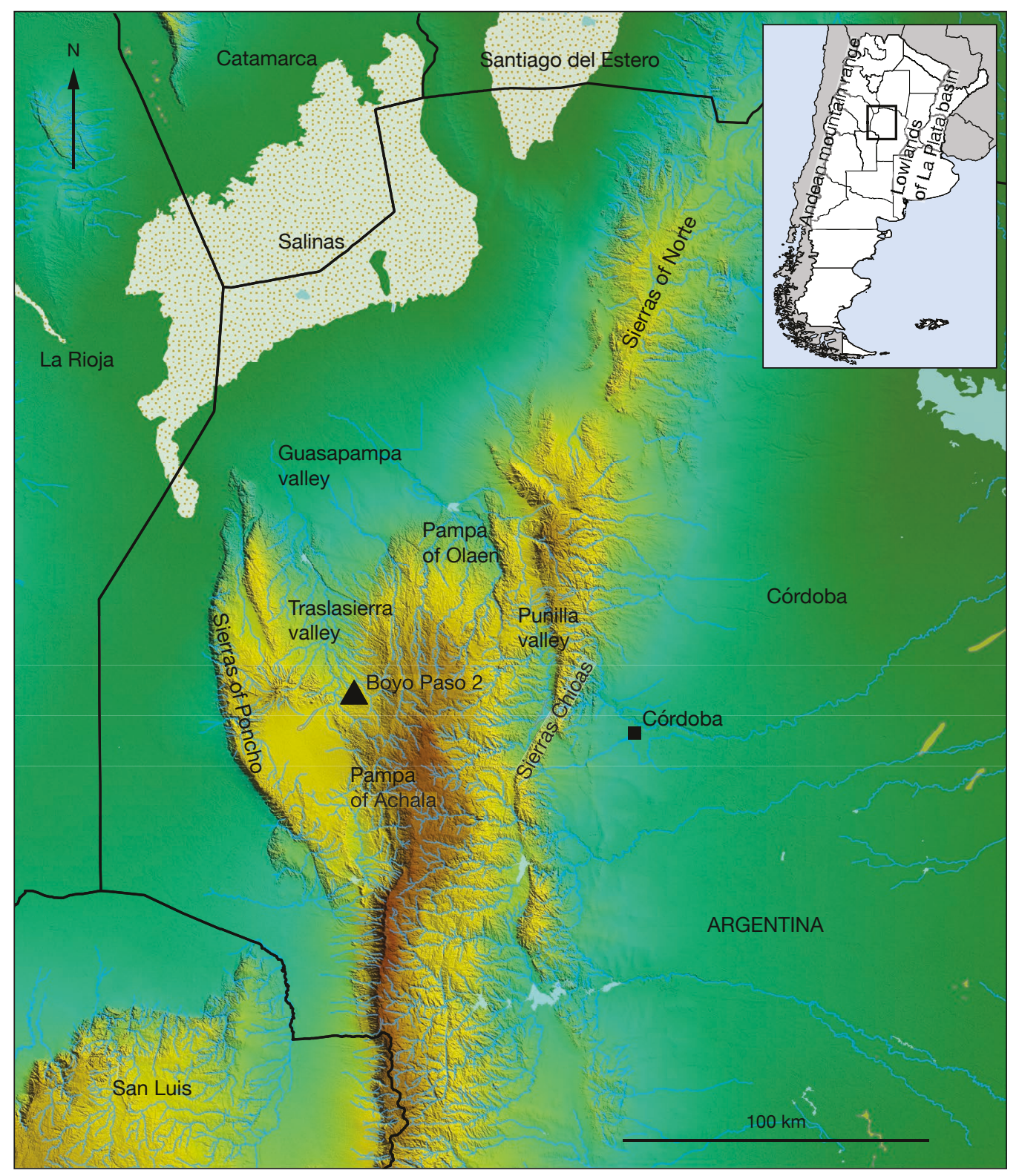

FIG. 1. - Geographic location of Boyo Paso 2 (Sierras of Córdoba, Argentina).

\section{MATERIAL AND METHOD}

The study is focused on the 3777 faunal remains obtained during the excavation of Boyo Paso 2, including those recovered on the archaeological floor and during sieving in $1.5 \mathrm{~mm}$ mesh screen. Eggshells were considered the by-products of the initial developmental stage of birds and were included in the analysis. The specimens were washed, sorted and analyzed following standard protocols (Lyman 1994; Outram 2004; Stiner 2005). Every bone or teeth specimens were identified to its most specific level as possible using reference collection. The portion (i.e., proximal, medial, distal), laterality and epiphyseal fusion stage were recorded as well as the shape of bone fracture outlines. Cultural (cut, percussion and burnt marks) and non-cultural (carnivore tooth marks and digestive damage) modifications were also documented according to Blumenschine et al. (1996), Stiner (2005) and Medina et al. (2012), in order to differentiate the animal bones that were incidentally incorporated from those that were intentionally exploited in the past human subsistence. Regarding Rheidae eggshells, their taxonomic identification was performed by quantifying shell pore-density, since Rheidae species show well-known statistically significant variability in this characteristic (Apolinaire \& Turnes 2010) $)^{1}$. Burning damage according to Medina et al. (2011) and other marks inflicted on eggshells as engraved decorative or intentional perforations were examined as well.

1. The pores were counted in $1 \mathrm{~cm}^{2}$ areas using a Nikon 3D100 Camera and Photoshop CS6 modified digital images. Species assignation was carried out using density intervals defined by modern samples of greater rhea (Rhea americana (Linnaeus, 1758)) -72 to 108 pores $/ \mathrm{cm}^{2}$ - and lesser rhea (Rhea pennata d'Orbigny, 1834) -36 to 63 pores $/ \mathrm{cm}^{2}$ (Apolinaire \& Turnes 2010). 


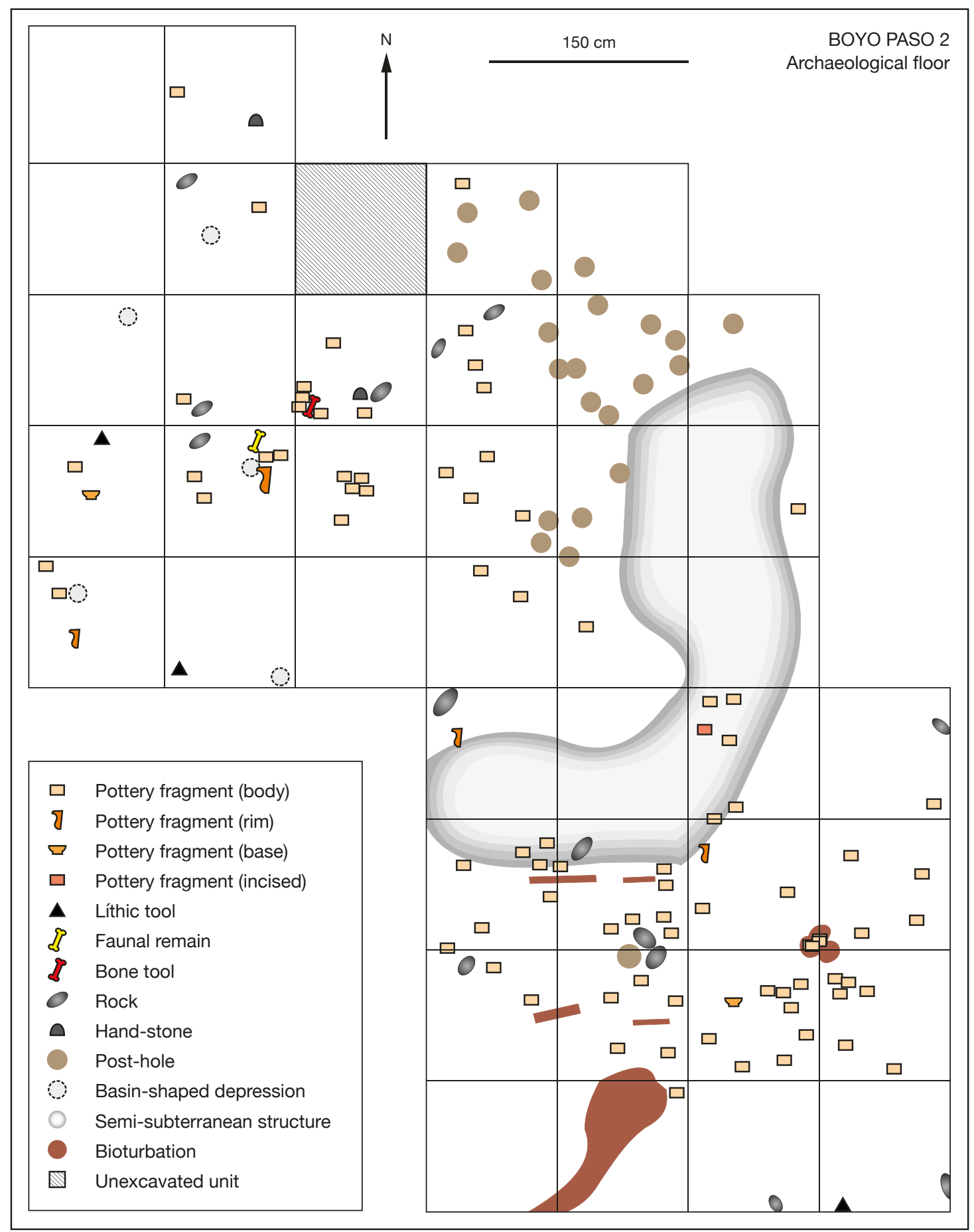

FIG. 2. - Plain view of the archaeological floor from Boyo Paso 2 with the excavation units, post-molds and key features.

Taxonomic abundance was quantified as the Number of Identified Specimens per Taxon (NISP), also expressed as bone-based NISP, teeth-based NISP and NISP\%. Teeth were quantified as separate entities, regardless whether they were found articulated or isolated to facilitate the inter-assemblage comparability despite post-depositional processes that might have affected them (Stiner 2005; Lyman 2008). Number of Specimens (NSP) and Number of Unidentified Specimens
(NUSP) were also considered (Lyman 2008). The extent of fragmentation, or how broken the bones of the assemblage are, was measured by the relation NISP/NSP excluding eggshells (Lyman 2008; Wolverton et al. 2011). In general, as NISP/ NSP increase, fragments are smaller and then less identifiable.

Lama guanicoe was the most profitable but at the same time the most vulnerable to human predation prey type in Sierras of Córdoba due to its isolated distribution in the upper 
TABLE 1. - Boyo Paso 2 faunal remains. Abbreviations: NISP, number of identified specimens per taxon; NSP, number of specimens; NUSP, number of unidentified specimens.

\begin{tabular}{|c|c|c|c|c|c|c|c|}
\hline Taxa & Vernacular name & NISP & $\begin{array}{c}\text { Cut- } \\
\text { marks } \\
\text { (NISP) }\end{array}$ & $\begin{array}{c}\text { Anthropic } \\
\text { fractures } \\
\text { (NISP) }\end{array}$ & $\begin{array}{c}\text { Burned } \\
\text { (NISP) }\end{array}$ & $\begin{array}{l}\text { Tooth- } \\
\text { marks } \\
\text { (NISP) }\end{array}$ & $\begin{array}{c}\text { Digestive } \\
\text { damage } \\
\text { (NISP) } \\
\end{array}$ \\
\hline Lama cf. L. guanicoe (Müller, 1776) & Guanaco & 178 & 25 & 9 & 56 & 0 & 0 \\
\hline Mazama sp. Rafinesque, 1817 & Brocket deer & 4 & 1 & 1 & 2 & 0 & 0 \\
\hline Ozotoceros bezoarticus Linnaeus, 1758 & Pampas deer & 21 & 6 & 1 & 4 & 0 & 0 \\
\hline Cervidae cf. O. bezoarticus (Linnaeus, 1758) & Pampas deer? & 9 & 2 & 1 & 4 & 0 & 0 \\
\hline Cervidae, sp. Indet & Brocked deer, pampas deer, etc. & 76 & 15 & 2 & 14 & 0 & 0 \\
\hline Cetartiodactyla cf. Tayassuidae & Peccary? & 1 & 0 & 0 & 0 & 0 & 0 \\
\hline Cetartiodactyla, sp. Indet. & Guanaco, deer, etc. & 73 & 3 & 2 & 20 & 0 & 0 \\
\hline Lycalopex sp. Burmeister, 1854 & Fox & 2 & 0 & 0 & 0 & 0 & 0 \\
\hline Chaetophractus vellerosus Gray, 1865 & Small hairy armadillo & 79 & 1 & 0 & 6 & 0 & 0 \\
\hline Chaetophractus villosus Desmarest, 1804 & Large hairy armadillo & 1 & 1 & 0 & 0 & 0 & 0 \\
\hline Chaetophractus sp. Fitzinger, 1871 & Hairy armadillo & 5 & 0 & 0 & 1 & 0 & 0 \\
\hline Zaedyus cf. Z. pichiy Desmarest, 1804 & Pichi? & 1 & 0 & 0 & 0 & 0 & 0 \\
\hline Euphractinae, sp. Indet. & Armadillo & 14 & 0 & 0 & 0 & 0 & 0 \\
\hline Dasypodidae, sp. Indet. & Armadillo & 3 & 0 & 0 & 0 & 0 & 0 \\
\hline Dolichotis patagonum Zimmermann, 1780 & Patagonian cavy & 1 & 1 & 0 & 0 & 0 & 0 \\
\hline Lagostomus maximus Desmarest, 1817 & Plains vizcacha & 1 & 0 & 0 & 0 & 0 & 0 \\
\hline Ctenomys sp. Blainville, 1826 & Tuco-tuco & 65 & 11 & 0 & 0 & 0 & 0 \\
\hline Caviinae, sp. Indet. & Cavy & 9 & 2 & 0 & 0 & 0 & 0 \\
\hline Caviomorpha, sp. Indet. & Cavy, tuco-tuco, etc. & 2 & 0 & 0 & 0 & 0 & 0 \\
\hline Akodon dolores Thomas, 1916 & Shrubland mouse & 3 & 0 & 0 & 0 & 0 & 0 \\
\hline Calomys cf. C. venustus Thomas, 1894 & Mouse & 3 & 0 & 0 & 0 & 0 & 0 \\
\hline Sigmodontidae cf. Calomys Waterhouse, 1837 & Mouse & 1 & 0 & 0 & 0 & 0 & 0 \\
\hline Holochilus sp. Brandt, 1835 & Red marsh rat & 4 & 0 & 0 & 0 & 0 & 0 \\
\hline Cricetidae, sp. Indet. & Mouse & 8 & 0 & 0 & 0 & 0 & 0 \\
\hline Rodentia, sp. Indet. & Rat, tuco-tuco, cavy, etc. & 26 & 0 & 0 & 0 & 0 & 0 \\
\hline Mammalia, sp. Indet & Mammal (medium-large size) & 241 & 33 & 6 & 67 & 0 & 0 \\
\hline Mammalia, sp. Indet & Mammal (small size) & 13 & 1 & 0 & 2 & 0 & 0 \\
\hline Nothura sp. Wagler, 1827 & Tinamou & 4 & 3 & 0 & 1 & 0 & 0 \\
\hline Tinamidae cf. Nothura Wagler, 1827 & Tinamou & 6 & 3 & 0 & 2 & 0 & 0 \\
\hline Tinamidae, sp. Indet. & Tinamou & 4 & 1 & 0 & 0 & 0 & 0 \\
\hline Zenaida auriculata (Des Murs, 1847) & Dove & 1 & 1 & 0 & 0 & 0 & 0 \\
\hline Columbidae, sp. Indet. & Dove & 1 & 0 & 0 & 0 & 0 & 0 \\
\hline Catheridae cf. Cathartes Illiger, 1811 & Vulture & 2 & 1 & 0 & 0 & 0 & 0 \\
\hline Falconidae cf. Caracara Merrem, 1826 & Caracara & 2 & 1 & 1 & 0 & 0 & 0 \\
\hline Falconidae, sp. Indet. & Eagle, caracara, hawk & 1 & 1 & 0 & 0 & 0 & 0 \\
\hline Fulica, sp. Indet. & Coot & 1 & 0 & 0 & 0 & 0 & 0 \\
\hline Rhea sp. (Brisson, 1760) & South-american ostrich (bone) & 1 & 1 & 0 & 0 & 0 & 0 \\
\hline Rhea cf. $R$. americana (Linnaeus, 1758) & Greater rhea (eggshell) & 6 & 0 & 0 & 0 & 0 & 0 \\
\hline Rhea cf. $R$. pennata d'Orbigny, 1834 & Lesser rhea (eggshell) & 13 & 0 & 0 & 0 & 0 & 0 \\
\hline Rhea sp. & South-american ostrich (eggshell) & 372 & 0 & 0 & 96 & 0 & 0 \\
\hline Passeriformes, sp. Indet. & Bird (small size) & 1 & 1 & 0 & 0 & 0 & 0 \\
\hline Underterminated Bird & Bird (small size) & 4 & 0 & 0 & 1 & 0 & 1 \\
\hline Underterminated Bird & Bird (small size) & 2 & 0 & 0 & 0 & 0 & 0 \\
\hline Tupinambis sp. (Daudin, 1802) & Tegu lizard & 6 & 2 & 0 & 0 & 0 & 0 \\
\hline Reptilia, sp. Indet. & Reptile (small size) & 2 & 0 & 0 & 0 & 0 & 0 \\
\hline Amphibia, sp. Indet & Frog, toad, etc. & 1 & 0 & 0 & 0 & 0 & 0 \\
\hline NUSP & & 2453 & 172 & 160 & 851 & 0 & 0 \\
\hline NSP & & 3777 & 289 & 183 & 1127 & 0 & 1 \\
\hline
\end{tabular}

mountain grassland range, a "faunistic island" of $6000 \mathrm{~km}^{2}$ surrounded by chaquenian forest (Rivero \& Medina 2016). It was predicted that $L$. guanicoe was always pursued upon encounter, but also that the loss of an individual had several consequences on its demography because there is no population replacement. Only if the encounter rate of $L$. guanicoe decreases due to climatic change or human induced depression, the diet should be broadened to include more abundant low-return resources and carcass exploitation should increase. Thus, the archaeological frequency of $L$. guanicoe bone remains in the record and how intensively its carcass-was exploited to obtain animal fat would reflect its abundance in the landscape
(Broughton 1999). In consequence, camelid specimens were examined at fine scale, focusing the analysis of the resource intensification on it.

The age of death in Camelidae bones was identified at coarsegrain as adults or young individuals based on epiphyseal fusion (Kaufmann 2009). Adults include completed fused bones while young individuals consider unfused and semi-fused bones. The relative frequencies of young individual to adults ( $\sum$ (young individuals $/ \sum$ [young individuals + adults])) is used to provide a measure of the age structure of the exploited population, in order to assess if human harvest pressure caused a reduction in the mean and maximum ages of wild herds (Broughton 1999). 
The skeletal parts of L. guanicoe transported to Boyo Paso 2 were quantified by the NISP, the Normed NISPs (NNISP) ${ }^{2}$ and the Minimum Number of Elements (MNE) (Lyman 1994; Broughton 1999; Grayson \& Frey 2004; Stiner 2005), in order to assess L. guanicoe exploitation strategy under the resource depression proposed by Rivero \& Medina (2016). Their economically utility was studied by the Mean Food Utility Index (Mean FUI), calculated as $\Sigma($ NNISP $\mathrm{i} \times$ FUIi $) / \Sigma N N I S P$ (Broughton 1999: 59) ${ }^{3}$. Thus, an assemblage with high mean utility values would relatively suggest a more dominant frequency of high utility skeletal elements and vice versa. However, NNISP of different elements was compared to volumetric density (Elkin 1995), in order to assess density-mediated bone attrition. This study considered the highest volume density values for particular element, being consistent with the hypothesis that the stronger portion of the bone would be the one to be preserved and identified (Lyman 1994: 270).

In order to determine the diet breadth from the carcass point of view and if highly-grease-values portion of camelids were more intensively fragmented for grease extraction, the study considered the relative abundance (NISP/MNE) of high grease utility ends of four elements: the humerus, radius, femur and tibia (Wolverton et al. 2011). It was assumed that high NISP per MNE signifies intense fragmentation for more efficiently grease extraction and that render portions should be less identifiable. The study also assumed that phalanges are lowest-marrow utility elements and if \%whole decreases or is low, an intensive fragmentation for marrow occurred (Wolverton et al. 2011). Thus, the percentage of camelid whole phalange 1 and 2 were used to measure how intensive the marrow extraction was and to assess if $L$. guanicoe decreases in its local abundance, forcing people to intensify its-carcass exploitation. Unfused phalanges were not considered during the quantification (Wolverton et al. 2011). However, burning damage would also produce highly fragmented assemblage and it was considered using the relative abundance of burnt marks on NISP and NUSP (Lyman 2008).

Finally, the maximum camelid bones weathering stage was also described to assess the taphonomic history of L. guanicoe bones, the conservation status of the sample and the span of time that the skeletal elements were accumulated as a rough proxy of duration, intensity and continuity of site occupation (Behrensmeyer 1978).

2. The NNISP was defined by Grayson \& Frey (2004: 31) as the number of identified specimens per anatomical part normed by the number of times that part occurs in the skeleton of the specie involved. These values are not scaled because the analysis is based on rank order correlation and scaling skeleta abundance does not change their relative ranks (see also Broughton 1999:58). The NNISP was selected mainly for the simplicity of its calculation in a site that today continues being excavated and because of the fact that is not subject to aggregation effects as MNE and other derived measures with which the NNISP is correlated (Grayson \& Frey 2004).

3. The body part economic utility was roughly assessed using the Food Utility Index (FUI) made by Metcalfe \& Jones (1988) for reindeer (Rangifer tarandus (Linnaeus, 1758)), only to provide a simple gross measure for inter-assemblage comparison. Borrero (1990) published a L. guanicoe meat utility index that correlates with $R$. tarantus model, showing that Metcalfe \& Jones (1988) data is applicable to archaeological situation with guanaco bones and facilitate future comparison with other taxa as cervids.
TABLE 2. - Main characteristics of Boyo Paso 2 bone assemblage focusing on Lama cf. L. guanicoe (Müller, 1776) and excluding eggshells. Abbreviations: MNE, minimum number of elements; NISP, number of identified specimens per taxon; NSP, number of specimens.

\begin{tabular}{lc}
\hline General characteristics of bone assemblage & BP2 \\
NSP & 3384 \\
NISP & 931 \\
NSP:NISP & 3.64 \\
\hline Characteristic of Lama cf. L. guanicoe bone assemblage & \\
NISP & 178 \\
Bone-based NISP & 128 \\
Teeth-based NISP & 50 \\
Frequencies of subadults to adults & 0.51 \\
Mean Food Utility Index & 2078.58 \\
\%Whole phalanx 1 and 2 & $17.39 \%$ \\
Median NISP:MNE & 1.64 \\
Median NISP:MNE of high grease elements & 2 \\
(humerus,radius, femur, tibia, calcaneus and & \\
metapodials) & $25 \%$ \\
$\%$ Ends of humerus and radius & $28.57 \%$ \\
$\%$ Ends of femur and tibia & $18.87 \%$ \\
\%NISP with cut-marks & $(\mathrm{NISP}=24)$ \\
\%NISP with burned damage & $31.46 \%$ \\
\%NISP with anthropic fractures & $(\mathrm{NISP}=56)$ \\
& $7.08 \%$ \\
& $(\mathrm{NISP}=9)$ \\
\hline
\end{tabular}

\section{RESULTS}

Table 1 displays the various taxa identified at Boyo Paso 2. The extent of fragmentation (NISP/NSP) displayed in Table 2 and Fig. 3 shows a very fragmented faunal assemblage, a situation that resulted in the identification of most specimens only to body-size classes as Mammalia (medium-large size). The highest percentage of burned NUSP $(82.55 \%)$ related to burned NISP $(17.45 \%)$ indicates that burning damage was the most probable cause of high fragmentation and consequently lowlevel specific identification.

Despite fragmentation, Lama sp. was the largest readily consumed faunal resource assigned to genus or species level (Tables $1 ; 2)$. They were tentatively assigned to the wild camelid Lama cf. L. guanicoe. Evidence of domesticated Lama glama Linnaeus, 1758 and herding strategies during the Late Prehispanic Period was still weak (Medina et al. 2014) and was not taken into account.

Camelid bones bear cut-marks (Table 2) related to primary and secondary butchery activities. Other common modifications include impact scars (Table 2), probably produced during marrow extraction and/or to reduce the size of the bone into portion that can be readily placed in ceramic cooking pots, one of the most abundant artifacts reported on-site (Medina et al. 2016). The low percentage of whole phalanges and the relation NISP/MNE should be associated with an intense fragmentation of the camelid carcass for grease and marrow extraction, a situation that would explain the high frequency of NUSP or specimens assigned to body-size classes (Table 1).

Burnt marks have high frequencies in camelid bones (Table 2). Because fire figures predominantly in food preparation technologies of most human cultures (Wranghan 2009), it is reasonable to expect that at least some burning of bone stems 


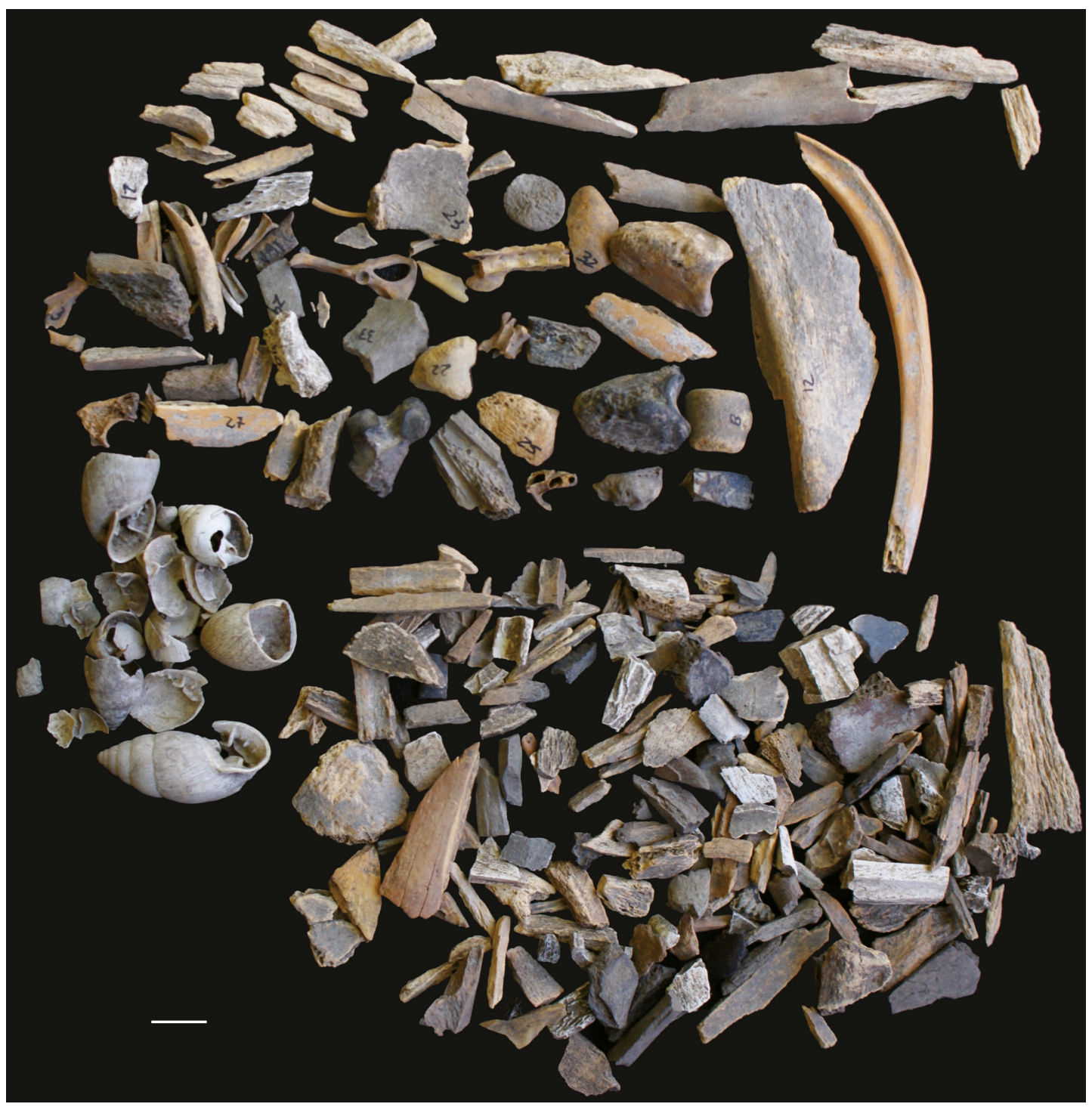

FIG. 3. - Part of the faunal assemblage collected on the archaeological floor. Scale bar: $10 \mathrm{~mm}$.

directly from cooking activities. However, such explanation is quite limited because many of the smaller pieces of bones were nearly fully carbonized and this pattern looks more related to post-depositional process rather than cooking.

The most abundant bone-weathering stage displayed by the camelid bones is the Behrensmeyer (1978) stage 2 (Fig. 4). Weathering stage 0 or extremely weathered specimens were absent. Moreover, some camelid bones were worked into tools. One of them consists in a scapula expediently transformed into a notched tool used for scraping wild or domesticated Oxalis tuberosa Molina, 1782 (Medina et al. 2018).

Mortality pattern includes a balanced representation of adults and young individuals (mostly sub-adults younger than 34-36 months, where unfused bones of early fusion stage were absent), suggesting that a large percentage of individuals were hunted before reaching maturity (Table 2). However, the mortality profile has a low resolution to indicate either if the site was occupied during the wet season or on an annual basis. Skeletal representation was dominated by scapulae (Table 3), but also included phalanges, radioulnae, autopodials, femur and tibiae. No correlation with volumetric density was found ( $r s=0.17 ; p>0.05)$. Thus, mineral density-mediated preservation does not seem to be a major factor to explain the pattern, even when future studies need to take into account the ontogenic variability in L. guanicoe bone density (Alvarez et al. 2010: 101) and some alternatives to traditional correlation analysis as focusing on elements with a similar likelihood of surviving (Lam \& Pearson 2005: 106, 107). Moreover, the Mean FUI of skeletal parts was 2078.58 (Table 2), higher than other semi-permanent late prehispanic village assemblages (Medina \& Pastor 2012). This pattern sheds light for a body part selection toward high-utility elements. It also supports the hypothesis that hunting and butchering were carried out on distant patches from Boyo Paso 2, transported and finally consumed at site. 


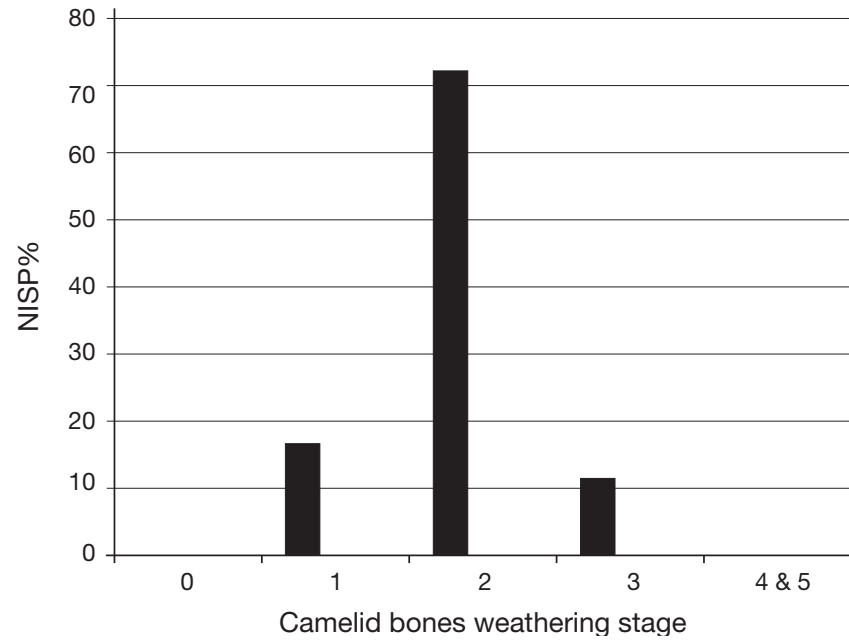

FIG. 4. - Weathering profile for Lama cf. L. guanicoe (Müller, 1776) bones from Boyo Paso 2 (Córdoba, Argentina) (N=79).

Cervids were the other Cetartiodactyla recorded at site. Two species were identified: pampas deer (Ozotoceros bezoarticus (Linnaeus, 1758)) and brocket deer (Mazama sp. Rafinesque, 1817). O. bezoarticus is a gregarious deer adapted to open vegetation environment that was hunted in the upper mountain grassland range $c .10 \mathrm{~km}$ of the site. Mazama sp. is a small deer well-adapted to close environments surrounding the site. Bones of both cervids were presented in low frequency, maybe invisible in the assemblage by fragmentation.

Identified birds are mostly represented by eggshells assigned to the family Rheidae (Table 1). Currently, the nesting season of Rheidae is spring-summer (October-January) and their presence in Boyo Paso 2 confirmed that the site was occupied at least in early wet season. Two Rheidae species were identified by the pore-density technique: Rhea cf. $R$. americana (Linnaeus, 1758) and Rhea cf. $R$. pennata d'Orbigny, 1834 (Table 1). However, most specimens were assigned to Rhea sp. (Brisson, 1760) allowing high-rates of postdepositional destruction, with most fragments limited to $10-20 \mathrm{~mm}$ in maximum dimension. High-percentage of NISP that compromises burned specimens (Table 1) suggests burning related fragmentation (Table 1). Taphonomic attributes, as whether the Boyo Paso 2 eggshell specimens are consequence of natural bird nesting, broken eggs used as containers or human food refuse, are ambiguous to determine. However, the absence of intentional human perforation or engraved motifs on eggs excludes the possibility of use as a liquid container, artifact widely documented in the ethnographic and archaeological record (e.g. Stiner 2005; Kandel \& Conard 2005; Fiore \& Borella 2010; Carden \& Martínez 2014). Furthermore, the eggshell density, its association to lithic, pottery and bone artifacts, the presence of two Rhea species and the burned eggshell frequency indicate an unequivocal human food refuse association. Even though burning damage is not a good indicator of human consumption, its recurrence may be used as circumstantial evidence to suggest that the eggs were transported and cooked in hearths or over coals,
TABLE 3. - NISP, NNISP and MNE of Lama cf. L. guanicoe (Müller, 1776) from Boyo Paso 2 (Córdoba, Argentina). Abbreviations: MNE, Minimum Number of Elements; NNISP, normed number of identified specimens per taxon; NISP, number of identified specimens per taxon.

\begin{tabular}{lccc}
\hline Skeletal element & NISP & NNISP & MNE \\
\hline Skull & 1 & 1 & 1 \\
Teeth & 50 & - & - \\
Hiodes & 1 & 1 & 1 \\
Mandible & 0 & 0 & 0 \\
Atlas & 0 & 0 & 0 \\
Axis & 0 & 0 & 0 \\
Cervical vertebrae & 4 & 0.8 & 1 \\
Throracic vertebrae & 5 & 0.41 & 3 \\
Lumbar vertebrae & 5 & 0.71 & 2 \\
Caudal vertebrae & 2 & 0.13 & 1 \\
Rib & 19 & 1.3 & 4 \\
Sternum & 1 & 0.16 & 1 \\
Scapula & 5 & 2.5 & 3 \\
Humerus & 0 & 0 & 0 \\
Radius ulna & 4 & 2 & 3 \\
Carpals & 9 & 1.2 & 9 \\
Pelvis & 2 & 1 & 1 \\
Femur & 3 & 1.5 & 2 \\
Patella & 4 & 2 & 4 \\
Tibia & 13 & 1.65 & 8 \\
Astragalus & 6 & 0.7 & 6 \\
Calcaneum & 4 & 2 & 2 \\
Tarsals & 3 & 1.5 & 3 \\
Metapodium & 0 & 0 & 0 \\
Sesamoid & 8 & 1.6 & 8 \\
Phalanx 1 & 7 & 1.7 & 4 \\
Phalanx 2 & 8 & 0.5 & 8 \\
Phalanx 3 & 14 & 1.75 & 5 \\
\hline
\end{tabular}

a practice that has been recorded in Patagonia ethnographic documents (Musters 1997; Claraz 2008). Despite eggshells, Rheidae bone elements are represented only by an isolated distal tarsometatarsus of a young individual.

Medium-sized mammals as foxes (Lycalopex sp. Burmeister, 1854) and armadillos were also well documented in the assemblage, the later mainly represented by bony dermal scutes (Table 1). The species Chaetophractus vellerosus (Gray, 1865), Ch. villosus (Desmarest, 1804) and cf. Zaedyus pichiy (Desmarest, 1804) were identified. Armadillos have a more active behavior during the warm season (Carlini et al. 2016), where the possibility of capture increases. Thus, their presence in Boyo Paso 2 it is interpreted as summer seasonal markers of site occupations.

Caviomorph rodents (Dolichotis patagonum (Zimmermann, 1780), Lagostomus maximus (Desmarest, 1817), Ctenomys sp. Blainville, 1826, Caviinae, etc.), cricetid rodents (Akodon dolores Thomas, 1916, Calomys cf. C. venustus (Thomas, 1894), Holochilus sp. Brandt, 1835), birds (Nothura sp. Wagler, 1827, Zenaida auriculata (Des Murs, 1847), Fulica sp. Linnaeus, 1758, Caracara sp. Merrem, 1826, Cathartes sp. Illiger, 1811, etc.) and reptiles (Tupinambis sp. Daudin, 1802) were also identified in the Boyo Paso 2 faunal assemblage. Gnawing marks of carnivores were absent. Digestive damage on their bone surfaces was only associated to a small bird bone (rounded category, sensu Bochenski \& Tomek 1997) and it was assigned to digestion caused by diurnal or nocturnal raptors as Strigiformes, Accipitriformes or Falconiformes. In contrast, 
diverse small-taxa bore unequivocal traces of human interaction such as cut marks or burning damage in distal end of long bones (Table 1). Small-sized rodents Akodon dolores and Calomys cf. $C$. venustus are the exception and their presence on-site is probably due to natural causes. Something similar occurred with the large-sized cricetid Holochilus, even when in other archaeological assemblages their bones have burnt or cut-marks that support a human accumulation (Medina et al. 2012). Most of these species are year-round resident of the Sierras of Cordoba. The exception is the tegu lizard (Tupinambis sp.), which has a more active behavior from October to April (Fitzgerald et al. 1994) when it was captured, processed and consumed. A vulture proximal humerus assigned to cf. Catharthes was interpreted as a by-product of bone tool manufacturing. The specimen presents evidence of cut-and-break technique across the circumference of the shaft in order to obtain a cylinder to make a tool.

Finally, gastropod shells were identified in the assemblage, but not treated in this paper. Most archaeological specimens were assigned to the genus Plagiodontes Doering, 1876, a common landsnail of the Sierras of Córdoba. Their presence was interpreted as naturally trapped in the slightly depressed living floor of pit-houses during abandonment phases.

\section{DISCUSSION}

The detailed faunal analysis carried out in Boyo Paso 2 produced a useful dataset for assessing the economic organization of Sierras of Córdoba late prehispanic people, mostly when the frequency cutmarks, percussion marks and, eventually, the high-frequency of burning damage on bones indicate that humans were the main agents that formed this faunal assemblage. Only the origins of few small birds and cricetid rodent bones remained ambiguous or were accumulated by raptors, being excluded from the economic analysis. Thus, the samples offer an excellent opportunity to assess without taxonomic ambiguity the human subsistence through the Late Prehispanic Period and the role that hunting played in mixed cultivation and foraging economies.

Lama cf. L. guanicoe was the most important faunal resource consumed in the studied site when body-size is considered, confirming that hunting this wild ungulate in the upper mountain grassland range continues being an important economic activity for late prehispanic people, even when its archaeological abundance in relation to previous archaic occupations decreases (Rivero \& Medina 2016). Evidence collected here indicates that wild camelids were not mainly used for food, but also as raw materials for bone tools manufacturing (Medina et al. 2018). Likewise, the uniformity of bone-weathering stage, being dominated by weathering stage 2 , implies that caution should be taken in assuming a good conservation of the assemblage and that most of camelid bones were accumulated over a short-span of time, a condition that reinforces the short-term site-use interpretation, even when only a rough estimation of the occupation span can be imposed.
The prey mortality pattern shows a high frequency of young individuals that normally were marginally of the optimal diet (Rivero \& Medina 2016). The high hunting rate of young individuals is interpreted as a result of a decrease in L. guanicoe encounter rate derived by long-term human predation and habitat fragmentation, which effectively depressed prey availability and forced late prehispanic people to be less selective to kill young individuals (Rivero \& Medina 2016).

The camelid mean body part utility was relatively high, reflecting that hunters needed to travel greater distance to seem large prey and were selective regarding the body part transported to the seasonal base-camps. Results also show that low-utility skeletal elements transported to Boyo Paso 2 were intensively processed, reinforcing the hypothesis of a Late Holocene decrease in prey encounter rate. The extent of fragmentation and the low percentage of whole phalanges, as well as the frequencies of cut-marks and human-induced fractures, support these arguments.

However, the high frequency of burning damage in the assemblage cannot be ignored. The evidence indicates that the archaeological deposit of Boyo Paso 2 was accumulated along decades or centuries, averaging human behaviors and multiple post-depositional processes. At archaeological scale resolution, the bones deposited in the earliest occupations may have been cleared for reusing some areas and burnt by overlapping fires made during later reoccupations. Because burning makes bones more susceptible to fragmentation (Stiner 2005; Costamagno et al. 2005), the fragmented characteristic of Boyo Paso 2 assemblage would be related to the dynamic with which late prehispanic people occupied and reoccupied the site on the seasonal basis, mostly when unburned bones usually exhibited unequivocal traces of anthropic-induced fractures and the history of small burned pieces assigned to NUSP was less clear. In consequence, burning damage-mediated decomposition by mechanical processes as trampling is the foremost, or the most immediate, probable cause of bone breakage in the Boyo Paso 2 record, especially if people visited it repeatedly at the long-term as it is proposed. Likewise, the hypothesis requires further investigation and other forms of attrition must be considered exploring the multiple dimension of burned bones as the intensity or grades of burning sorted by colors, frequency of body part affected, size of burned specimens, morphologies of fractures, etc. (Outram 2004; Stiner 2005; Costamagno et al. 2005; Lyman 2008).

Medium-to-small vertebrates and Rheidae eggs were also identified in the assemblage, showing that they played an integral role in subsistence behaviors. These resources are not commonly recorded previously to the Late Prehispanic Period. Their abundance is undoubtedly due to their local abundance availability and high nutritional values in term of proteins, calories and other elements as fur. However, their presence is also interpreted in term of a decrease of the Lama cf. L. guanicoe encounter frequency as a consequence of human hunting pressure across the Holocene, forcing late prehispanic people to broaden their diet to include more abundant small-game ignored by early archaic foragers. 
Medina et al. (in press) proposed that the effective exploitation of a wide range of terrestrial vertebrates in Sierras of Córdoba occurred after the advent of the bow $c .1500 \mathrm{BP}$, which in Boyo Paso 2 is suggested by tiny lithic projectile points assigned to arrow point. Bow hunting expands the capturable prey size range to large-to-small vertebrates and reduces problems of overtaking swift preys. The increase of hunting efficiency has several consequences to L. guanicoe demography because it accelerates the predation pressure initiated by archaic foragers and stresses the possibility of local extinction, a situation clearly monitored by their declination in the late prehispanic record and the unselective hunting of young individuals. However, the use of hunting passive technologies as snares or traps needs to be considered, mainly as it would provide meat without search cost and it is a low-risk strategy for a reliable daily feeding, regardless it can be accomplished by different age-class members of a nuclear family. Unfortunately, only lithic and bone projectile points survived the post-depositional process. Bow and elements of trap technologies were not preserved in the record because they are normally made of sinew, cordage, wood or other biodegradable materials.

The predation of the south-american ostrich is only suggested by eggshell specimens. Rhea bones were rarely found, a common pattern that challenges zooarchaeologists analyzing Pleistocene-Holocene assemblages from the Neotropic (see Apolinaire \& Turnes 2010; Medina et al. 2011). A possible explanation of their absence may be related to the fact that $R$. americana and $R$. pennata were preys difficult to hunt or their meat was a widespread food taboo, a symbolic behavior that have rarely been taken into consideration despite the long-standing recognition in the ethnographic record (Politis 2007: 293). Another reason would include that carcasses were not discarded on-site, were fragmented into smallunidentified pieces and/or were destroyed by bone mineral density-mediated attritional processes, hypotheses in which future research needs to be focused.

\section{CONCLUSION}

Abundant contextual information suggests that the faunal remains recovered in Boyo Paso 2 were accumulated through a complex sequence of late prehispanic reoccupations (albeit for the same season) where bones were deposited, accidentally reburned and fragmented to small pieces by the daily domestic trampling or other mechanical post-depositional processes. Despite that, the faunal assemblage shows that a broad hunting spectrum continued playing a key role in Late Prehispanic Period, instead cultigens were fluctuating components in a diverse foraging economy in which wild plant and animal resources continued to be extensively used (Medina et al. 2016).

The adoption of on-site plant cultivation $c .1500 \mathrm{BP}$ from the Boyo Paso 2 point of view did not produce any dramatic or revolutionary change in subsistence or in mobility. The zooarchaeological evidence presented here supports that cultivation fitted conveniently into pre-existing diversified forager pattern and its adoption occurred primarily as an opportunistic effort to minimize a seasonally occurring productive shortfall rather than promoting other subsistence related activities.

Thus, the evidence draws to the conclusion that foraging and plant cultivation were important facets of a subsistence economy. Paleoecological and settlement pattern survey data indicates that late prehispanic people moved around the landscape to take advantage of both wild resources and domesticated as they became available. Some predictable resources were likely exploited on a planned or scheduled basis, mostly those resource clumps in patches as L. guanicoe, crops and Prosopis spp. fruits. Other resources were probably procured through opportunistic foraging when large quantities were encountered near the sites as small-prey and a variety of low-return wild fruits. Foraging provides the bulk of the overall diet and probably dominates the activities scheduled by adults, while farming activities were limited to field preparation, planting, harvesting and processing so as not interfere with foraging wild food where available. Although such horticultural strategy played an ancillary role and presented risk of crop fail, the associated cost were very low and the potential payoff high. The development of a diversified economy, in consequence, was accompanied by a high residential mobility, co-residential group fission-fusion mechanisms and the abandonment of crop field to forage, where the local resource abundance was weighted in term of the regional foraging potential.

To conclude, one of the main properties resulting from the faunal analysis presented here is the diversity of preys exploited. This at least shows the niche breadth during the Late Prehispanic Period and highlights the importance of minimizing the cost of failure in the capture of the prey they depended on. The results also outline the importance of hunting among groups traditionally interpreted as sedentary farmers which, along with harvesting wild and domesticated plants, scheduled the annual mobility cycle. So, there is little reason to think that the adoption of plant cultivation in Sierras of Córdoba sprang as a single entity and quickly derived in a full-sedentary farming, even when it is difficult to estimate the reliance on cultivated plants over foraging from the few crop macro-remains and microfossils recovered on sites. Many potential dimensions of the human niche are likely to have been developed independently. Archaeologists who study the spread of food-producing economies must identify the different forms and levels of mixed economies as well as provide answers to why certain cultivators eventually decided to be more sedentary while other were organized as seasonal or occasional food producers. Ethnographic examples of reversion to forage by people who previously practiced cultivation are known in the literature (i.e., Layton et al. 1991; Freeman 2012; Bulbeck 2013), but remained poorly documented archaeologically due to the absence of the adequate frameworks for their recognition in the archaeological record. Thus, how prehispanic foragers adjusted their foraging activities to plant cultivation is a question that should drive much of the modern archaeological research. And the properties and characteristics of animal food remains left by Sierras of Córdoba late prehispanic people would constitute a model to interpret other archaeological cases where the boundaries between farming and foraging were fluid, but remained relatively invisible according to the existing terminology. 


\section{Acknowledgements}

We thank the financial support by the Consejo Nacional de Investigaciones Científicas y Técnicas (CONICET PIP 112200801-02678) and the Agencia Nacional de Promoción Científica y Tecnológica (PICT-2012-0995). Our acknowledgements also extend to S. Pastor, R. Hoguin, C. Quintana, L. Prates, M. Cardillo, E. Mange, A. Pucheta and D. Gobbo, who provided professional advices, equipment and replied to our numerous requests to improve the original. Thanks also to M. Mondini and the anonymous referee of Anthropozoologica for their careful readings and valuable advices.

\section{REFERENCES}

Alvarez M. C., Gonzalez M., Massigoge A., Kaufmann C. \& GuTIERrEZ M. 2010. — La densidad mineral ósea y la variabilidad ontogénica en guanaco (Lama guanicoe). Implicancias para la construcción de marcos de referencia en zooarqueología, in Gutierrez M., De Nigris M., Fernandez P., Giardina M., Gil A., IZETA A., Neme G. \& YACOBACcio H. (eds), En Zooarqueología a principios del siglo XXI. Aportes teóricos, metodológicos y casos de estudio. Ediciones del Espinillo, Buenos Aires: 65-75.

AMKREUTZ L., VANMONTFORT B. \& VERHART L. 2008. — Diverging trajectories? Forager-farmer interaction in the southern part of the Lower Rhine Area and the applicability of contact models, in Hofman D. \& Bickle P. (eds), Creating Communities. New Advances in Central European Neolithic Research. Oxbow Books, Oxford: 11-31.

Apolinaire E. \& Turnes L. 2010. - Diferenciación específica de Reídos a partir de fragmentos de cáscaras de huevos. Su aplicación en sitios arqueológicos del Holoceno Tardío, in BERON M., Luna L., Bonommo M., Montalvo C., Aranda C. \& Carrera Aizpitarte M. (eds), Mamül Mapu: pasado y presente desde la Arqueología Pampeana. Editorial Libros del Espinillo, Ayacucho: 215-222.

Asouti E. \& FAIRBAiRn A. 2010. — Farmers, gatherers or horticuralists? Reconstructing landscapes of practice in the Early Neolithic, in FINLAYSON B. \& WARREN G. (eds), Landscapes in Transition. Oxbow Book, Oxford: 162-172.

BANDY M. \& Fox J. (eds) 2010. — Becoming Villagers: Comparing Early Village Societies. University of Arizona Press, Tucson, 368 p.

BARLOW K. R. 2002.-Predicting maize agriculture among the Fremont: an economic comparison of farming and foraging in the American Southwest. American Antiquity 67 (1): 65. https:// doi.org/10.2307/2694877

BEHRENSMEYER A. K. 1978. - Taphonomic and ecologic information from bone weathering. Paleobiology 4 (2): 150-162. https:// doi.org/10.1017/S0094837300005820

Blumenschine R. J., Marean C. W. \& Capaldo S. D. 1996. Blind test of inter-analyst correspondence and accuracy in the identification of cut marks, percussion marks, and carnivore tooth mark on bone surface. Journal of Archaeological Science 23 (4): 493-507. https://doi.org/10.1006/jasc.1996.0047

Bochenski Z. \& TomeK T. 1997. - Preservation of bird bones: erosion versus digestion by owls. International Journal of Osteoarchaeology 7 (4):372-387. https://doi.org/10.1002/(SICI) 10991212(199707/08)7:4<372::AID-OA355>3.0.CO;2-W

BORRERO L. 1990. — Fuego-Patagonian bone assemblages and the problem of communal guanaco hunting, in DAVIS L. \& REEVES B. (eds), Hunters of the Past. Unwin Hyman, London: 373-399.

Broughton J. M. 1999. - Resource Depression and Intensification during the Late Holocene, San Francisco Bay. Evidence from the Emeryville Shellmound Vertebrate Fauna. University of California Press, Berkeley, 150 p.
BULBECK D. 2013. - The transition from foraging to farming in prehistory and 'ethnography'. World Archaeology 45 (4): 557-573. https://doi.org/10.1080/00438243.2013.821668

Carden N. \& Martínez G. 2014. - Diseños fragmentados. Circulación social de imágenes sobre huevos de Rheidae en Pampa y Norpatagonia. Boletín del Museo Chileno de Arte Precolombino 19 (2): 55-75. https://doi.org/10.4067/S0718-68942014000200004

Carlini A. A., Soibelzon E. \& Glaz D. 2016. — Chaetophractus vellerosus (Cingulata: Dasypodidae). Mammalian Species 48 (937): 73-82. https://doi.org/10.1093/mspecies/sew008

Claraz G. 2008. - Viaje al Rio Chubut. Aspectos Naturalisticos y Etnológicos (1865-1866). Ediciones Continente, Buenos Aires, $288 \mathrm{p}$.

Costamagno S., Théry-Parisot I., Brugal J.-P. \& Guibert R. 2005. - Taphonomic consequences of the use of bones as fuel: experimental data and archaeological applications, in O'Connor T. (ed.), Biosphere to Lithosphere. New Studies in Vertebrate Taphonomy. Oxbow Books, Oxford: 51-62.

Denham T. P., Iriarte J. \& VRYDAGHS L. (eds) 2007. - Rethinking Agriculture. Archaeological and Ethnoarchaeological Perspectives. Left Coast Press, Walnut Creek, 476 p. (Coll. One World Archaeology; 51)

Dillehay T., Rossen J. \& STACKelbeck K. 2011. — Foraging to farming and community development, in Dillehay T. (ed.), From Foraging to Farming in the Andes: New Perspectives on Food Production and Social Organization. Cambridge University Press, Cambridge: 257-273.

ElKIN D. C. 1995. - Volume density of South American camelid skeletal parts. International Journal of Osteoarchaeology 5 (1): 29-37. https://doi.org/10.1002/oa.1390050104

Fiore D. \& Borella F. 2010. — Geometrías delicadas: diseños de gravados en cáscaras de huevo de Rheidae recuperados en la costa norte del Golfo de San Matías, Rio Negro. Intersecciones en Antropología 11 (2): 277-293.

FitzFerald L., Porini G. \& Lichtschein V. 1994. — El Manejo de Tupinambis en Argentina: historia, estado actual y perspectivas futuras. Interciencia 19 (4): 166-170.

FrEEMAN J. 2012. — Alternative adaptive regimes for integrating foraging and farming activities. Journal of Archaeological Science 39 (9): 3008-3017. https://doi.org/10.1016/j.jas.2012.04.039

Grayson D. K. \& FreY C. J. 2004. - Measuring skeletal part representation in archaeological faunas. Journal of Taphonomy 2 (1-4): $27-42$

Kandel A. W. \& CONARD N. J. 2005. - Production sequences of ostrich eggshell beads and settlement dynamics in the Geelbek Dunes of the Western Cape, South Africa. Journal of Archaeological Science 32 (12): 1711-1721. https://doi.org/10.1016/j. jas.2005.05.010

KAUfMANN C. A. 2009. - Estructura de edad y sexo en guanaco: estudios actualisticos y arqueológicos en Pampa y Patagonia. Sociedad Argentina de Antropología, Buenos Aires, 320 p.

KenNETT D. J. \& WINTERHALDER B. (eds) 2006. - Behavioral Ecology and the Transition to Agriculture. University of California Press, Berkeley, 408 p.

LAM Y. \& PEARSON M. 2005. - Bone density studies and the interpretation of the faunal record. Evolutionary Anthropology 14 (3): 99-108. https://doi.org/10.1002/evan.20053

Layton R., Foley R. \& Williams E. 1991. - The transition between hunting and gathering and the specialized husbandry of resources: a socio-ecological approach. Current Anthropology 32 (3): 255-274. https://doi.org/10.1086/203953

López L. 2015. - Prácticas culinarias como medio para la reproducción social de los grupos prehispánicos de las sierras de Córdoba, in Salazar J. (ed.), Condiciones de posibilidad de la reproducción social en sociedades prehispánicas y coloniales tempranas en las Sierras Pampeanas (República Argentina). Centro de Estudios Históricos "Prof. Carlos S.A. Segreti", Córdoba: 177-212. 
López L. \& RECALDE M. 2016. - The first quinoa (Chenopodium quinoa Willd) macrobotanical remains at Sierras del Norte (Central Argentina) and their implication in pre-Hispanic subsistence practices. Journal of Archaeological Science: Reports 8: 426-433. https://doi.org/10.1016/j.jasrep.2016.06.053

LyMAN R. 1994. - Vertebrate taphonomy. Cambridge University Press, Cambridge, $524 \mathrm{p}$.

LYMAN R. 2008. - Quantitative paleozoology. Cambridge University Press, Cambridge, 348 p.

Medina M. \& Pastor S. 2012. - Zooarqueología de Sitios Residenciales Tardíos de las Sierras de Córdoba (Argentina, ca. 1100300 AP): Avances y Perspectivas, in Acosta A., LoponTE D. \& Mucciolo L. (eds), Temas de Arqueología, Estudios Tafonómicos y Zooarqueológicos II. Instituto Nacional de Antropología y Pensamiento Latinoamericano, Buenos Aires: 45-66.

Medina M., Pastor S., Apolinaire E. \& Turnes L. 2011. — Late Holocene subsistence and social integration in Sierras of Córdoba (Argentina): the South-American ostrich eggshells evidence. Journal of Archaeological Science 38 (9): 2071-2078. https://doi org/10.1016/j.jas.2011.05.001

Medina M., Teta P. \& Rivero D. 2012. - Burning damage and small-mammal human consumption in Quebrada del Real 1 (Córdoba, Argentina): an experimental approach. Journal of Archaeological Science 39 (3): 737-743. https://doi.org/10.1016/j. jas.2011.11.006

Medina M., Pastor S. \& Rivero D. 2014. - Osteometría y diferenciación de especies de camélidos en sitios arqueológicos de las Sierras Centrales (Argentina). Tendencias, problemas y perspectivas. Intersecciones en Antropología 15 (2): 339-351.

Medina M., Pastor S. \& Recalde A. 2016. — The archaeological landscape of Late Prehispanic mixed foraging and cultivation economy (Sierras of Córdoba, Argentina). Journal of Anthropological Archaeology 42: 88-104. https://doi.org/10.1016/j.jaa.2016.04.003

Medina M., López L. \& BUC N. 2018. - Bone tool and tuber processing: a multi-proxy approach at Boyo Paso 2, Argentina. Antiquity 92 (364): 1040-1055. https://doi.org/10.15184/aqy.2018.93

Medina M., Balena I. \& Rivero D. (in press). - Proyectiles y procesos de intensificación: una aproximación desde Boyo Paso 2, 1500-750 AP (Sierras de Córdoba, Argentina). Chungara, Revista de Antropología Chilena.

MetCAlFe D. \& JONES K. T. 1988. - A reconsideration of animal body-part utility indices. American Antiquity 53 (3): 486-504. https://doi.org/10.2307/281213

Muscio H. 2009. - El Formativo es una unidad analítica inadecuada en la arqueología evolutiva del NOA, in LÓPEZ G. \& CARDillo M. (eds), Arqueología y evolución. Teoría, metodología $y$ casos de estudio. Editorial SB, Buenos Aires: 197-213.
Musters G. 1997. - Vida entre los Patagones. Editorial El Elefante Blanco, Buenos Aires, 384 p. [1st ed. 1869-1871]

Outram A. 2004. - Bone fracture and within-bone nutrients: an experimentally based method for investigating levels of marrow extraction, in Miracle P. \& Milner N. (eds), Consuming Passions and Patterns of Consumption. McDonald Institute for Archaeological Research, Cambridge: 51-64.

PASTOR S. \& LÓPEZ L. 2010. - Consideraciones sobre la agricultura prehispánica en el sector central de las Sierras de Córdoba, in Korstanje A. \& Quesada M. (eds), Arqueología de la agricultura: casos de estudio en la Región Andina Argentina. Editorial Magma, Tucumán: 208-233.

Pastor S., Medina M., Recalde A., López L. \& Berberian E. 2012. - Arqueología de la región montañosa central de argentina. Avances en el conocimiento de la historia prehispánica Tardía. Relaciones de la Sociedad Argentina de Antropología 37: 89-112.

POLITIS G. 2007. - Nukak. Ethnoarchaeology of an Amazonian People. Lef Coast Press, Walnut Creek, $411 \mathrm{p}$.

Popov A., Tabarev A. \& Mikishin Y. 2014. - Neolithization and Ancient Landscapes in Southern Primorye, Russian Far East. Journal of World Prehistory 27 (3-4): 247-261. https://doi. org/10.1007/s10963-014-9073-1

PRICE D. \& GeBAUER A. (eds) 2003. - Last Hunters, First Farmers. New Perspectives on the Prehistoric Transition to Agriculture. School of American Research Press, Santa Fe, 372 p.

RECALDE A. \& LÓPEZ L. 2017. — Las sociedades prehispánicas tardías en la región septentrional del centro de Argentina (Sierras del Norte, Córdoba). Avances a su conocimiento desde los recursos vegetales. Chungara 49 (4): 573-588. https://doi.org/10.4067/ S0717-73562017005000109

Rivero D. \& MEDINA M. 2016. - Human colonization, diet breadth and niche construction during Sierras of Córdoba Holocene (Argentina), in Muscio H. \& CARDILlo M. (eds), Darwin's Legacy: the State of Evolutionary Archaeology in Argentina. Archaeopress, Oxford: 67-81. (Coll. South American Archaeology Series; 24).

SiLVA F. \& Frank R. 2013. - Deconstructing the Neolithic myth: the implications of continuity for European Late Prehistory. Anthropological Notebooks 19: 223-235.

STINer M. 2005. - The Faunas of Hayonim Cave, Israel. Peabody Museum Press, Cambridge, $330 \mathrm{p}$.

Wolverton S., Nagaoka L., Densmore J. \& Fullerton B. 2011. - White-tailed deer harvest pressure \& within-bone nutrient exploitation during the mid- to late Holocene in southeast Texas. Before Farming: the Archaeology and Anthropology of HunterGatherers 2008 (2), 23 p. https://doi.org/10.3828/bfarm.2008.2.3 Wranghan R. 2009. - Catching Fire. How Cooking Made us Human. Basic Books, New York, 309 p. 